\title{
High-resolution melting analysis identifies reservoir hosts of zoonotic Leishmania parasites in Tunisia
}

Moufida Derghal 1,4, Abir Tebai ${ }^{1}$, Ghofrane Balti ${ }^{2,3}$, Hajer Souguir-Omrani ${ }^{1}$, Jomaa Chemkhi ${ }^{1}$, Adel Rhim ${ }^{2,3}$, Ali Bouattour ${ }^{2,3}$, Ikram Guizani ${ }^{1}$, Youmna M'Ghirbi ${ }^{2,3}$ and Souheila Guerbouj ${ }^{* *}$ (1)

\begin{abstract}
Background: Leishmaniasis is endemic in Tunisia and presents with different clinical forms, caused by the species Leishmania infantum, Leishmania major, and Leishmania tropica. The life cycle of Leishmania is complex and involves several phlebotomine sand fly vectors and mammalian reservoir hosts. The aim of this work is the development and evaluation of a high-resolution melting PCR (PCR-HRM) tool to detect and identify Leishmania parasites in wild and domestic hosts, constituting confirmed (dogs and Meriones rodents) or potential (hedgehogs) reservoirs in Tunisia.
\end{abstract}

Methods: Using in vitro-cultured Leishmania isolates, PCR-HRM reactions were developed targeting the 7SL RNA and HSP70 genes. Animals were captured or sampled in El Kef Governorate, North West Tunisia. DNA was extracted from the liver, spleen, kidney, and heart from hedgehogs (Atelerix algirus) $(n=3)$ and rodents (Meriones shawi) $(n=7)$ and from whole blood of dogs $(n=12)$ that did not present any symptoms of canine leishmaniasis. In total, 52 DNA samples were processed by PCR-HRM using both pairs of primers.

Results: The results showed melting curves enabling discrimination of the three Leishmania species present in Tunisia, and were further confirmed by Sanger sequencing. Application of PCR-HRM assays on reservoir host samples showed that overall among the examined samples, 45 were positive, while seven were negative, with no Leishmania infection. Meriones shawi were found infected with L. major, while dogs were infected with L. infantum. However, coinfections with L. major/L. infantum species were detected in four Meriones specimens and in all tested hedgehogs. In addition, multiple infections with the three Leishmania species were found in one hedgehog specimen. Sequence analyses of PCR-HRM products corroborated the Leishmania species found in analyzed samples.

Conclusions: The results of PCR-HRM assays applied to field specimens further support the possibility of hedgehogs as reservoir hosts of Leishmania. In addition, we showed their usefulness in the diagnosis of canine leishmaniasis, specifically in asymptomatic dogs, which will ensure a better evaluation of infection extent, thus improving elaboration of control programs. This PCR-HRM method is a robust and reliable tool for molecular detection and identification of Leishmania and can be easily implemented in epidemiological surveys in endemic regions.

Keywords: Leishmania, High-resolution melting analysis, 7SL RNA, HSP70, Reservoir host, Tunisia

\footnotetext{
*Correspondence: souheila.guerbouj@gmail.com;

souheila.guerbouj@pasteur.tn

1 Laboratoire d'Epidémiologie Moléculaire Et Pathologie Expérimentale

Appliquée Aux Maladies Infectieuses (LR16IPT04), Institut Pasteur de

Tunis, Université Tunis El Manar, Tunis, Tunisia

Full list of author information is available at the end of the article
}

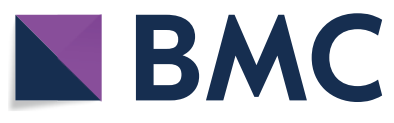
permits use, sharing, adaptation, distribution and reproduction in any medium or format, as long as you give appropriate credit to the original author(s) and the source, provide a link to the Creative Commons licence, and indicate if changes were made. The images or other third party material in this article are included in the article's Creative Commons licence, unless indicated otherwise in a credit line to the material. If material is not included in the article's Creative Commons licence and your intended use is not permitted by statutory regulation or exceeds the permitted use, you will need to obtain permission directly from the copyright holder. To view a copy of this licence, visit http://creativecommons.org/licenses/by/4.0/. The Creative Commons Public Domain Dedication waiver (http://creativeco mmons.org/publicdomain/zero/1.0/) applies to the data made available in this article, unless otherwise stated in a credit line to the data. 


\section{Background}

Leishmaniasis represents a group of protozoan parasitic diseases caused by species belonging to the genus Leishmania. It is endemic and occurs in more than 98 countries on five continents, with the exception of New Zealand and the southern Pacific [1]. So far, around 31 out of 53 identified Leishmania species have been reported to infect mammals, 20 of which cause various clinical manifestations in humans [1]. Worldwide, at least 70 species of wild and domestic animals, including dogs, opossums, bats, anteaters, sloths, marsupials, rodents, and hyraxes, have been identified as confirmed or potential reservoirs of Leishmania parasites [2]. In Tunisia, four clinical forms exist and are caused by different parasite species and hosted by various reservoirs. Visceral leishmaniasis (VL) is caused by Leishmania infantum, and its main reservoir is the dog [3], whereas for the sporadic cutaneous form (SCL) also due to this species, dogs are considered to be reservoirs [4]. Two other cutaneous forms exist in Tunisia, the highly endemic zoonotic cutaneous leishmaniasis (ZCL), which is caused by Leishmania major [4], and the chronic cutaneous leishmaniasis (CCL) caused by Leishmania tropica (syn. Leishmania killicki) [5]. These forms have as respective reservoirs rodents (Psammomys and Meriones) and gundies (Ctenodactylus gundi) [4, 6]. Recently, hedgehogs were identified as potential reservoirs of L. major in Iran [7]. A few years ago, in 2014, these animals were reported to be infected by L. major in both Atelerix algirus and Paraechinus aethiopicus in Algeria [8]. While in 2015, A. algirus hedgehogs were found to be co-infected by the two species L. major, and L. infantum in EL Kef Governorate, a region located in North West Tunisia and known to be endemic for SCL due to L. infantum [9]. These findings were later confirmed, suggesting the potential role of this animal as a reservoir host of leishmaniasis in Tunisia [10].

The methods used in these studies included various classical PCR techniques that target either non-coding or coding regions of the Leishmania genome [11]. However, these assays have multiple disadvantages, particularly regarding time consumption in post-PCR processing, including electrophoresis on agarose gels, confirmation with additional treatment by restriction fragment length polymorphism (RFLP), and sequencing, thus expending resources to overcome the challenge of spurious product generation during gene amplification with low sensitivity and high cost. Therefore, the development of other tools with higher sensitivity constitutes a better option for accurate detection and identification of Leishmania species in field-caught animals. Indeed, high-resolution melting PCR (PCR-HRM), which is a very sensitive amplification technique, enables the direct characterization of amplicons in a closed tube assay and does not require additional precautions to prevent crossover of PCR products [12]. It measures changes in the fluorescence intensity of a DNA-intercalating dye during dissociation from double-stranded DNA to single-stranded DNA, thus detecting single nucleotide polymorphism (SNP) [13]. In the last few years, this technique has become widely used to ensure better specificity, sensitivity, and reproducibility in molecular diagnostics of multiple diseases [12, 13]. To achieve robust Leishmania parasite detection and increase the sensitivity of the assays, previous studies applying PCR-HRM used markers present in abundant copy numbers in the Leishmania genome, including the heat shock protein 70 gene (HSP70) [14, 15], ITS1 sequences [14, 16], 7SL RNA gene [17], and LACK gene [18].

The aim of this study is the development and evaluation of molecular tools based on PCR-HRM to study Leishmania infection in wild and domestic mammal hosts constituting confirmed (dogs and rodents) and potential (hedgehogs) reservoirs of leishmaniasis in an endemic focus in North West Tunisia.

\section{Methods}

\section{Study site, animal identification, and sample collection}

The study was carried out in the governorate of EL Kef, which is situated in North West Tunisia and is known as an active focus of SCL due to $L$. infantum species. From 2015 to 2019 during leishmaniasis transmission seasons, field trips to three localities within this region (KaletSnen, Dahmani, and Zaafrann in Oued Souani) allowed us to capture different specimens of rodents (Meriones shawi; $n=7)$ and hedgehogs $(n=3)$. Additionally, blood samples and ocular/gum swabs were collected from dogs $(n=43)$ from the same region. After their transfer to the laboratory, hedgehogs and rodents were humanely euthanized and the corresponding genus and species were determined based on external morphological criteria $[19,20]$. Measurements of the body, head, ear, hind foot, and tail were systematically recorded for each specimen (Additional file 1: Table S1). Different types of samples were taken from each specimen, including liver, spleen, kidney, heart, lymph node, and skin. However, according to possibilities of sampling, gum swab, eye swab, blood, urine, fat, peritoneum, bone marrow, and liver nodules were also collected from some specimens (Additional file 2: Table S2). All samples were conserved in liquid nitrogen until later analysis. In addition, 27 Leishmania strains isolated from in vitro-cultured parasites representing the Old World species L. major, L. infantum, and L. tropica (Additional file 3: Table S3) were used to test the specificity of the developed PCR-HRM assays. 


\section{DNA extraction}

Whole genomic DNA was extracted from the biological material collected from dogs (blood $[n=43]$ and ocular/ gum swabs $[\mathrm{n}=52])$ as well as organ samples and biological liquids of Meriones $(\mathrm{n}=45)$ and hedgehogs $(\mathrm{n}=31)$ (Additional file 2: Table S2). All extractions were realized by the conventional phenol/chloroform method [21] and all DNA was suspended in $10 \mathrm{mM}$ Tris-1 mM EDTA p H8 solution and conserved at $+4{ }^{\circ} \mathrm{C}$. Extracted DNA was quantified using a Qubit Fluorometer (Invitrogen, France). Dilutions in DNAase/RNAase-free water at 50 or $20 \mathrm{ng} / \mu \mathrm{l}$ were prepared and used in PCR reactions.

\section{Development of PCR-HRM}

\section{Choice of target sequences and primer design}

Two gene sequences were targeted in this study. First, primers targeting a conserved region coding for the 7SL RNA subunit were used, as described previously [17]. This allowed amplification of a 119-base-pair (bp) DNA fragment. The second pair of primers targeting the HSP70 gene was designed here. Thus, using Clustal X, HSP gene sequences from $L$. major, $L$. infantum, and $L$. tropica were aligned and primers were designed in conserved regions flanking a 280-bp polymorphic internal region containing multiple SNPs, using the Primer3Plus software program (http://www.bioinformatics.nl/cgibin/ primer3plus/primer3plus.cgi). Primer-BLAST (http:// www.ncbi.nlm.nih.gov/tools/primer-blast/) was also used to check the primers' sequence specificity.

\section{Conventional PCR assays}

Prior to Leishmania DNA detection with PCR-HRM, both pairs of primers, 7SL RNA (CJ7SL/QRT7SL) and HSP70 (F_hsp70/R_hsp70), were tested by conventional PCR on DNA extracted from in vitro-cultured parasites representing Old World species L. major (MHOM/ TN/2011/EMPA10), L. infantum (MHOM/TN/94/LV50), and L. tropica (MHOM/IQ/65/L75) (Additional file 3: Table S3). PCR amplifications were set up using different concentrations of $\mathrm{MgCl}_{2}$, a gradient of annealing temperatures, and addition of dimethyl sulfoxide (DMSO) at 5\% and $10 \%$. In addition, their ability to detect Leishmania infection was tested using a collection of animal samples by conventional PCR primer pairs with the reaction conditions set up earlier. Absence of amplification found in several cases was monitored by repeating the PCR up to three times or, occasionally, by a re-amplification step of the first product. In order to assess the quality of newly extracted DNA, a PO (acidic ribosomal phosphoprotein) PCR targeting a 470-bp fragment in a conserved region of a mammalian gene [22] was carried out for all samples. To monitor for possible contamination, a negative control (no DNA) was introduced in all PCR reactions.
PCR conditions, cycling, and primer sequences used are reported in Additional file 4: Table S4.

\section{DNA sequencing and analysis}

Fragments generated by conventional PCR targeting 7SL RNA and HSP70 genes from each Leishmania strain used (L. major, L. infantum, L. tropica) as well as from animal samples were purified with phosphatase and exonuclease enzymes (Thermo Fisher Scientific, USA) and sequenced in both directions using the BigDye Terminator v3.1 Cycle Sequencing Kit (Applied Biosystems, USA). Sequencing was performed on an ABI 3500 sequencer (Applied Biosystems, USA). The generated sequences were visualized and manually corrected using BioEdit software, and then submitted to BLAST (basic local alignment search tool) analysis for homology searches using the National Center for Biotechnology Information (NCBI) server (http://blast.ncbi.nlm.nih.gov/). Direct sequencing assays were also carried out on PCR-HRM amplified products from animal samples, in order to confirm their Leishmania species identity and eventually validate ambiguous cases. The same sequencing procedure and analysis was followed as mentioned above.

\section{PCR-HRM development}

PCR-HRM development was first performed on control DNA extracted from in vitro-cultured strains of Leishmania species (L. major, L. infantum, and L. tropica). This was carried out with 7SL RNA and HSP70 gene primers by varying several parameters including a program with or without touchdown regarding the primer annealing temperatures, addition or no addition of DMSO at $5 \%$ or $10 \%$, and DNA concentrations. Then, in order to ensure clear discrimination between Leishmania species and to determine the accuracy and reliability of the method herein reported, developed conditions were applied on a panel of 27 Leishmania strains corresponding to several strains of L. major, L. infantum, and $L$. tropica species (Additional file 3: Table S3). The sensitivity of the PCR-HRM targeting 7SL RNA and HSP70 genes was determined using tenfold dilutions of DNA from each reference Leishmania isolate, representing $L$. infantum (MHOM/TN/94/LV50), L. major (MHOM/ TN/2011/EMPA10), and L. tropica (MHOM/IQ/65/L75). DNA amounts used were $20 \mathrm{ng}$ and a range of $10 \mathrm{ng}$ to $0.0001 \mathrm{ng}$.

PCR-HRM reactions were carried out in a final volume of $20 \mu$ l containing $20 \mathrm{ng}$ of DNA, $2 \times$ LightCycler $^{\circledR} 480$ High Resolution Melting Master Mix (Roche, France), $25 \mathrm{mM} \mathrm{MgCl}_{2}$ and $0.4 \mu \mathrm{M}$ of each primer. A LightCycler ${ }^{\circledR}$ 480 protocol (Roche, France) was then used, which included the following program: pre-incubation consisting of a denaturation step at $95{ }^{\circ} \mathrm{C}$ for $10 \mathrm{~min}$ followed 
by 45 cycles of amplification. The cycles comprised of the following steps: $95{ }^{\circ} \mathrm{C}$ for $10 \mathrm{~s}$, then a touchdown protocol for $15 \mathrm{~s}$ covering a range of annealing temperatures from 60 and $53{ }^{\circ} \mathrm{C}$ by decreasing $0.2^{\circ} \mathrm{C}$ at every cycle, followed by elongation at $72{ }^{\circ} \mathrm{C}$ for $10 \mathrm{~s}$. To obtain the melting curves, the PCR program was followed by a melting program, in which a dissociation of the amplicon was performed at $95{ }^{\circ} \mathrm{C}$ for $1 \mathrm{~min}$, then rapid cooling at $40{ }^{\circ} \mathrm{C}$ for $1 \mathrm{~min}$, followed immediately by a fusion step at $60^{\circ} \mathrm{C}$ for $1 \mathrm{~s}$, with ramp rates at $4.4,2.2$, and $1{ }^{\circ} \mathrm{C} / \mathrm{s}$, respectively for each step. Finally, melting curves were obtained by reassociation at $95{ }^{\circ} \mathrm{C}$, with a ramp rate of $0.02{ }^{\circ} \mathrm{C} / \mathrm{s}$ and 25 acquisitions $/{ }^{\circ} \mathrm{C}$, which are sufficient to result in a resolution appropriate for HRM analysis, as recommended by the manufacturer.

Results were analyzed using the LightCycler ${ }^{\circledR} 480 \mathrm{SW}$ 5.1 software package, including the gene scanning module (version 1.5.0), provided by the manufacturer. For each experiment, PCR efficiency was evaluated using the threshold cycle $(\mathrm{Ct})$ and melting curves were normalized according to obtained reaction values. Analysis of HRM results was realized by comparison of the obtained melting profiles to those corresponding to reference species (L. major, L. infantum, and L. tropica), which were systematically added as positive controls, in every reaction.

\section{Validation of the PCR-HRM tool on wild and domestic mammals}

The developed PCR-HRM was validated on DNA extracted from different samples $(n=52)$ from the studied animals: Meriones $(n=7)$, hedgehogs $(n=3)$, and dogs $(n=12)$ (Additional file 2: Table S2). Reaction conditions and programming, and melting curves normalization and analysis were performed as described earlier.

\section{Results \\ Development of PCR-HRM \\ Conventional PCR assays}

The specificity of 7SL (CJ7SL/QRT7SL) and HSP70 (F_ hsp70/R_hsp70) primers was determined by performing conventional PCR amplification, using genomic DNA extracted from in vitro-cultured parasites of three Leishmania species (L. infantum, L. major, and L. tropica). Amplified fragments at the expected sizes (119 bp and $280 \mathrm{bp}$, respectively) were found (Additional file 5: Fig. S1). In order to get a preliminary idea about Leishmania infection in collected animals (Meriones, hedgehogs, and dogs), these conventional PCRs were applied on the different samples, in addition to inclusion of L. infantum, $L$. major, and $L$. tropica representative species as positive controls. It is worth noting here that prior to the application of conventional 7SL and HSP70 PCRs, all DNA extracted from animal samples was subjected to PO PCR amplification and showed fragments at the expected 470-bp size (Additional file 6: Fig. S2). This PCR targets a mammalian gene whose amplification would provide information about the DNA quality and possible presence of inhibitors [22].

Using 7SL primers, the conventional PCR method failed to amplify the target Leishmania DNA in any of the animal samples, despite the addition of DMSO at various percentages (5\% and 10\%). However, expected fragments at $280 \mathrm{bp}$ were found using the second pair of primers targeting HSP70 genes (Additional file 5: Fig. S1). The results of PO and conventional 7SL and HSP70 PCRs on the DNA of animal samples are summarized in Table 1.

\section{Sequencing of conventional PCR products}

In order to assess the identity of amplified fragments obtained by conventional 7SL and HSP70 PCR from in vitro-cultured Leishmania parasites and on animal samples, direct Sanger sequencing was carried out. Thus, amplified products from LV50, EMPA10, and L75 isolates corresponding respectively to $L$. infantum, $L$. major, and $L$. tropica obtained by both pairs of primers (7SL and HSP70) were sequenced in both directions. Obtained sequences were subjected to BLAST searches and showed matches with the three corresponding Leishmania species sequences with significant coverage, identity percent and $E$ values (Additional file 7: Table S5). Sequencing results of HSP70 amplified products from samples of the collected Meriones showed infection with L. major of the liver and spleen of MZ1, spleen of MZ2, liver and kidney of MZ4, and liver of MZ7, while the spleen and kidney of MZ3, liver of MZ5, spleen and liver of MZ6, and spleen of MZ7 were found to be infected by L. infantum. Interestingly, the MZ7 specimen showed coinfection with both species L. infantum and L. major that were found in the spleen and liver samples, respectively (Table 1). For hedgehog specimens, the blood and liver of ED1, liver of ES1, and liver, spleen, and lymph node of EZ4 were found to be infected by L. major, while L. infantum was detected in the spleen and heart of ES1. Concerning dog specimens, the blood of $\operatorname{dog} 10, \operatorname{dog} 37$, and dog 43 was found to be infected by L. infantum (Table 1; Additional file 7: Table S5).

\section{PCR-HRM assays}

The PCR-HRM reaction setup was established through several optimization steps, which specifically included addition or no addition of DMSO at different concentrations, and the use of touchdown cycling for primer annealing. To obtain optimal conditions, experiments were first carried out using DNA extracted from the three reference species L. infantum, L. major, and L. tropica. Results showed distinguishable melting peaks based 
on different Tm values (Table 2), with 10\% DMSO and a touchdown program for $7 \mathrm{SL}$ primers, and 10\% DMSO, without touchdown, for HSP70 primers. To ensure reproducibility and specificity of our PCR-HRM assays, a panel of 27 Leishmania strains representing the three reference species (10 L. infantum, eight $L$. major, and nine $L$. tropica) were then tested using the same conditions, with both primers. Results showed that each reference species exhibited a distinct HRM profile with a specific Tm melting peak. Moreover, tested strains were grouped into three clusters, allowing their clear discrimination according to species identity (Fig. 1).

In order to determine the sensitivity of the PCR-HRM targeting 7SL and HSP70 genes, tenfold dilutions of DNA from each reference Leishmania isolate, representing $L$. infantum (MHOM/TN/94/LV50), L. major (MHOM/ TN/2011/EMPA10), and L. tropica (MHOM/IQ/65/L75), were used, ranging from $20 \mathrm{ng}$ to $0.1 \mathrm{pg}$ (DNA amount corresponding to $2 \times 10^{5}$ to one parasite [15]). The detection limit was $0.1 \mathrm{pg}$ DNA in L. tropica with both 7SL and HSP70 PCR-HRM, while $1 \mathrm{pg}$ was detected in $L$. infantum by 7SL PCR-HRM and 0.1 pg by HSP70 PCRHRM in the same species. In the case of L. major, HSP70 PCR-HRM allowed detection of $0.1 \mathrm{pg}$ of DNA and 7SL PCR-HRM $0.01 \mathrm{ng}$ (Additional file 8: Fig. S3). No fluctuation in melting curves or Tm values was obtained over the DNA concentration range examined for each species by either PCR-HRM tool (data not shown).

\section{Validation of PCR-HRM tool for Leishmania infection identification in reservoir animals}

We tested a total of 52 samples taken from seven Meriones $(n=23)$, three hedgehogs $(n=17)$, and 12 dogs $(n=12)$ using $7 \mathrm{SL}$ and HSP70 primers. The remaining animal samples were not processed by PCR-HRM due to limited resources in relation to the LightCycler ${ }^{\circledR} 480$ High Resolution Melting kit availability.

The results of the two assays were concordant, and both methods showed that overall among the total samples examined, 45 were positive while seven were negative, with no Leishmania infection (Table 1). The results were confirmed by repeating the experiments through two to three independent reactions according to the availability of DNA material (Table 1). Good Ct values were found, providing for each tested sample reliable $\mathrm{Tm}$ values that were in accordance with the ranges of the corresponding reference samples, thus allowing us not only to demonstrate the infection of corresponding organs with Leishmania, but also to assign them to appropriate species. Moreover, the gene scanning software facilitated samples analysis and allowed a clearer discrimination between species, which was observed through well-separated melting profiles for each Leishmania species, revealing distinct clusters. Examples of gene scanning analysis using the 7SL gene and melting peak analysis and using the HSP70 gene are given in Figs. 2 and 3.

This analysis allowed attributing to each infected animal sample a specific Leishmania species. Indeed, generally, samples extracted from Meriones were found infected with $L$. major while dogs were infected with $L$. infantum (Table 1; Fig. 2). Meanwhile, co-infections with L. major/L. infantum were also recorded for Meriones specimens MZ3, MZ5, MZ6, and MZ7 (Table 1). However, co-infections with $L$. major/L. infantum were found in all tested hedgehogs in different samples of the same specimen (ED1, ES1, and EZ4) (Table 1). Interestingly, infection with the three Leishmania species L. major, L. infantum, and L. tropica was found in ES1 hedgehog specimen (Table 1 ).

Sequence analysis of some of the PCR-HRM products using 7SL and HSP70 targets, corroborated the found Leishmania species in analyzed samples, as shown by the BLAST homology search (Table 1; Additional file 7: Table S5).

\section{Discussion}

In the last few years, HRM PCR has become more widely applied for epidemiological purposes related to infectious diseases in addition to genotyping yeasts, viruses, or bacteria [23-26]. Indeed, this technique allows distinction of the different viral or bacterial strains [23-25], detection of mutated and wild-type strains [13], mutations located on resistance genes, such as resistance to rifampicin in Mycobacterium tuberculosis [27], or differentiation between Brucella species [28]. In parasitology, HRM analysis is extensively applied for protozoan parasites. For example, based on the $18 \mathrm{~S}$ ribosomal gene, it allowed the rapid diagnosis of bovine babesiosis [29]. It was also evaluated to monitor Plasmodium falciparum treatment efficacy [30] and to detect and differentiate among Theileria annulata, Theileria orientalis, and Theileria sinensis species [31]. Taenia spp. and filarial worms are the helminths most frequently studied using this assay [32]. For leishmaniasis, HRM was used to identify L. infantum in canine serum samples [33]. In addition, it allowed the rapid discriminatory diagnosis of co-infecting Leptomonas seymouri with Leishmania donovani in clinical samples [34], the discrimination of Old World and New World Leishmania species [14-18], and also identification of this parasite in biopsies of patients with a different clinical manifestation of CL in Peru [35].

Tunisia is among the most leishmaniasis-affected countries in the world, with four co-endemic clinical forms. These forms are caused by different Leishmania species and hosted by various reservoirs including dogs, rodents (Psammomys and Meriones genus), gundies (C. gundi), 







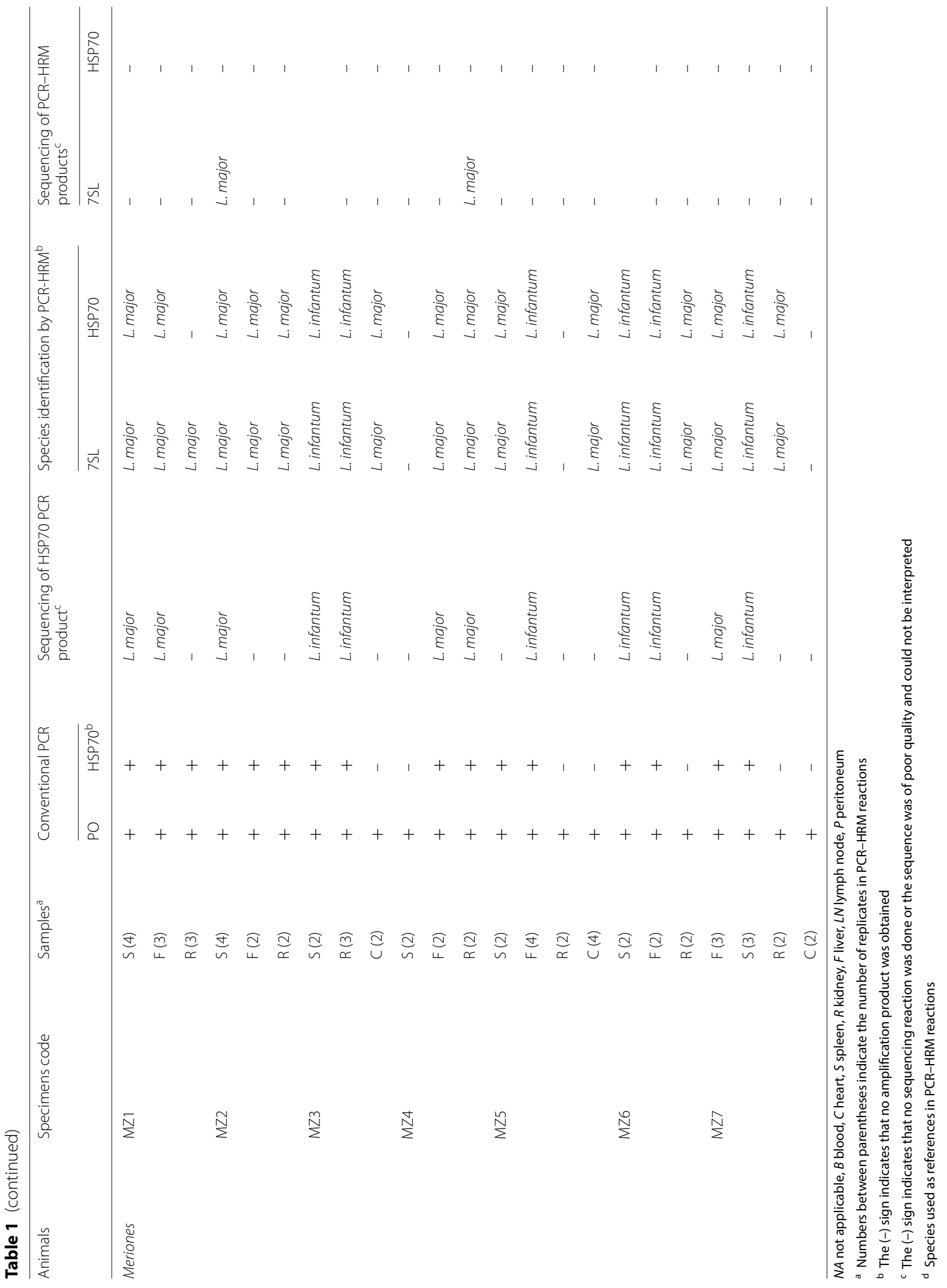


Table 2 Tm values of average melting curve peak for each Leishmania species

\begin{tabular}{lll}
\hline Species & \multicolumn{2}{l}{ Tm value range (mean Tm \pm SD) $\left({ }^{\circ} \mathrm{C}\right)$} \\
\cline { 2 - 3 } & $7 S L$ gene & HSP70 gene \\
\hline Leishmania major & $73.67 \pm 0.20$ & $70.60 \pm 0.07$ \\
Leishmania infantum & $72.67 \pm 0.35$ & $70.82 \pm 0.03$ \\
Leishmania tropica & $73.04 \pm 0.41$ & $69.92 \pm 0.03$ \\
\hline
\end{tabular}

weasels (Mustela nivalis), and hedgehogs (A. algirus and $P$. aethiopicus) $[4,9,10,36-39]$. In order to explore Leishmania infection in confirmed or suspected reservoir animals, several molecular markers and molecular techniques are available. These include mainly amplification by PCR coupled to RFLP and sequencing analyses. Since a low parasite load is expected to be present in reservoirs, especially when they are asymptomatic $[21,40]$, PCR assays always amplify genes with a high copy number in order to increase the sensitivity of detection. Thus, the kDNA, HSP70, and ITS1 molecular markers are among the most commonly used. Examples include demonstration of canine infection by L. (Viannia) guyanensis in the Brazilian Amazon using PCR and sequencing of HSP70 genes, upon DNA extraction from blood samples [41]. The presence of Leishmania parasites in the skin of different species of bats was also evaluated using kDNA PCR and PCR-RFLP analysis of the HSP70 gene in specimens collected in the Pantanal wetlands in Brazil [42] and also using nested PCR targeting the small subunit ribosomal RNA (SSU rRNA) gene in specimens from central western Brazil [43]. Also, PCR targeting ITS1 genes demonstrated Leishmania presence in different species of rodents in VL-endemic areas in Ethiopia [44]. Assessment of L. infantum infection in equine populations and in cats in visceral leishmaniasis transmission areas in Brazil was also possible with kDNA amplification from blood samples [45] and with ITS1 PCR from conjunctival swabs, respectively [46]. In Morocco, molecular detection of $L$. infantum and L. tropica in rodent species from endemic cutaneous leishmaniasis areas was assessed by PCR targeting the SSU rRNA and ITS1 genes, followed by sequencing [47].
Despite the extensive use of PCR and PCR-derived assays, their potential in detecting and identifying Leishmania infection, especially in reservoir animals, remains controversial. Indeed, in most cases, re-amplification or nested PCR is necessary to demonstrate Leishmania infection, and species identification requires additional steps, mainly RFLP and sequencing. Combining different PCR assays with different gene targets is also used. In addition, these methods are time consuming, especially in post-PCR processing, which increases the risk of DNA contamination. In this context, PCR-HRM methods may constitute a better choice for Leishmania infection detection and analysis in reservoir hosts, since they have the advantages of being simpler, less expensive, highly sensitive, and faster than conventional PCR assays. On average, PCR-HRM tests have been calculated to be five times cheaper and three times faster than other types of analysis such as multilocus sequence typing (MLST) and RFLP [48].

In the present study, we investigated Leishmania infection in a range of field samples taken from three hedgehogs, seven Meriones and 12 dogs captured in the same governorate of El Kef, situated in North West Tunisia, and constituting an active focus of SCL due to L. infantum. We used HRM PCR, which is a real-time PCR based on SYBR Green dye, with the Roche LightCycler ${ }^{\circledR}$ 480 machine equipped with gene scanning software (version 1.5.0). Development and optimization of PCRHRM targeting the 7SL RNA and HSP70 genes required modification of several reaction parameters, including a touchdown protocol, which ultimately improved amplification of the 7SL RNA gene targets. Also, the addition of DMSO enhanced both 7SL RNA and HSP70 PCR reactions. Previous studies have used touchdown PCR protocols to enhance specificity and product formation $[18,49]$. This approach offers a simple and rapid means of optimizing PCRs and specifically addresses the limitations inherent in Tm calculations, thus increasing sensitivity, specificity, and product formation [50]. Also, it largely relieves the need for lengthy optimization processes and redesign of primers [51].

The sensitivity of HSP70 PCR-HRM tool reached $0.1 \mathrm{pg}$ of Leishmania DNA, equivalent to one parasite, in

(See figure on next page.)

Fig. 1 Gene scanning analysis showing discrimination of 27 strains representing the three Leishmania species L. infantum, L. major, and L. tropica with PCR-HRM using 7SL RNA (a) and HSP70 (b) genes. Leishmania strains used are L. major ( $n=8$; EMPA10, IL32, Ron 44, EMPA11, EMPA12, Ron155, IL53, and FMH); L. infantum ( $n=10$; IPT1, LV08, LV10, LV49, LV50, D5, D8, D1 1, D13, and D16); and L. tropica ( $n=9$; K27, LA28, L75, Adhanis, Gabai159, Bumm30, Rachnan, Bag9, and Bag17) 


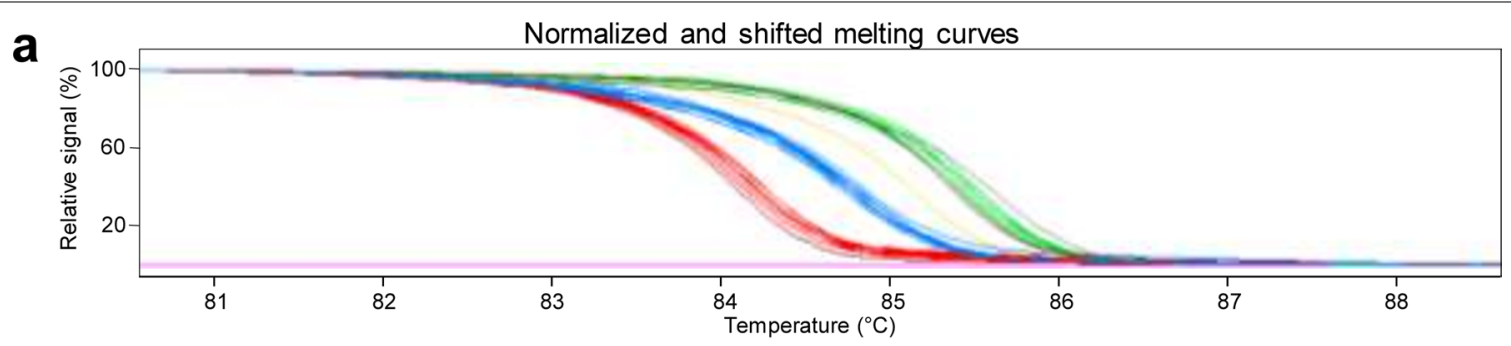

Normalized and temperature-shifted difference plot

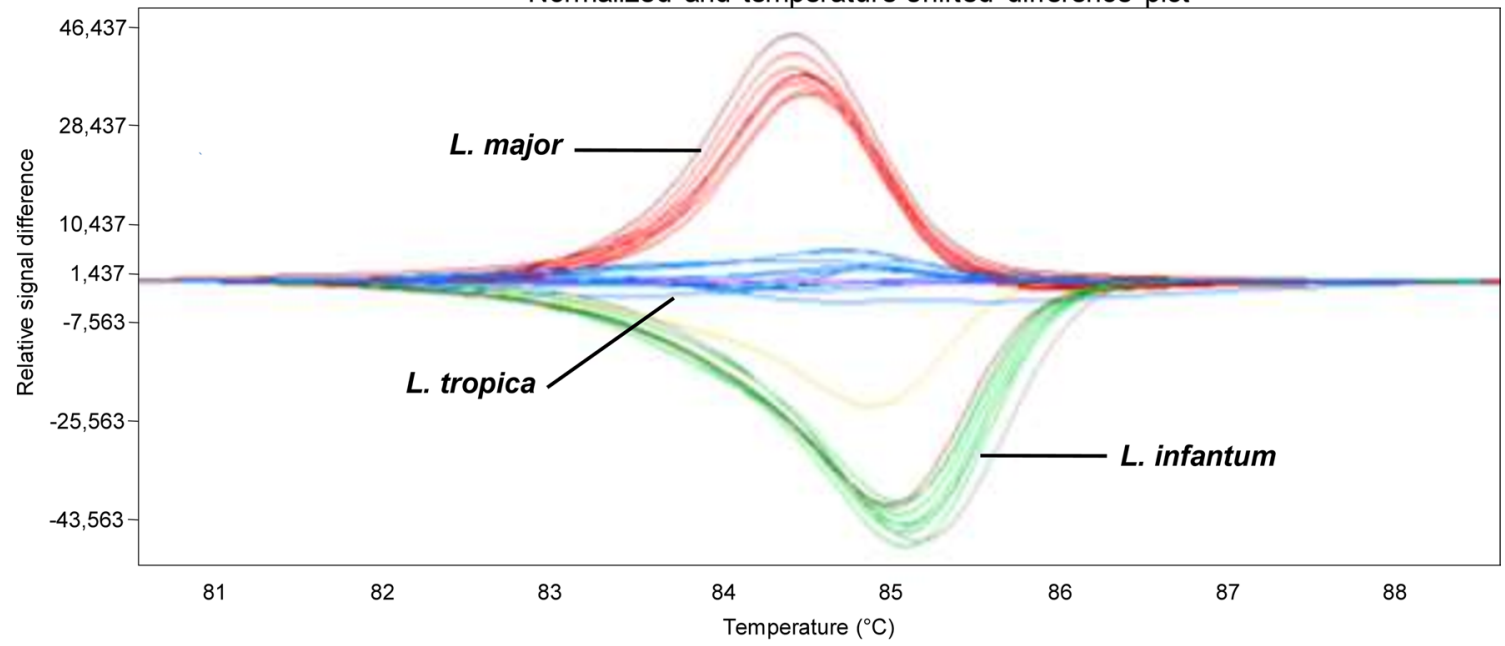

b

Normalized and shifted melting curves
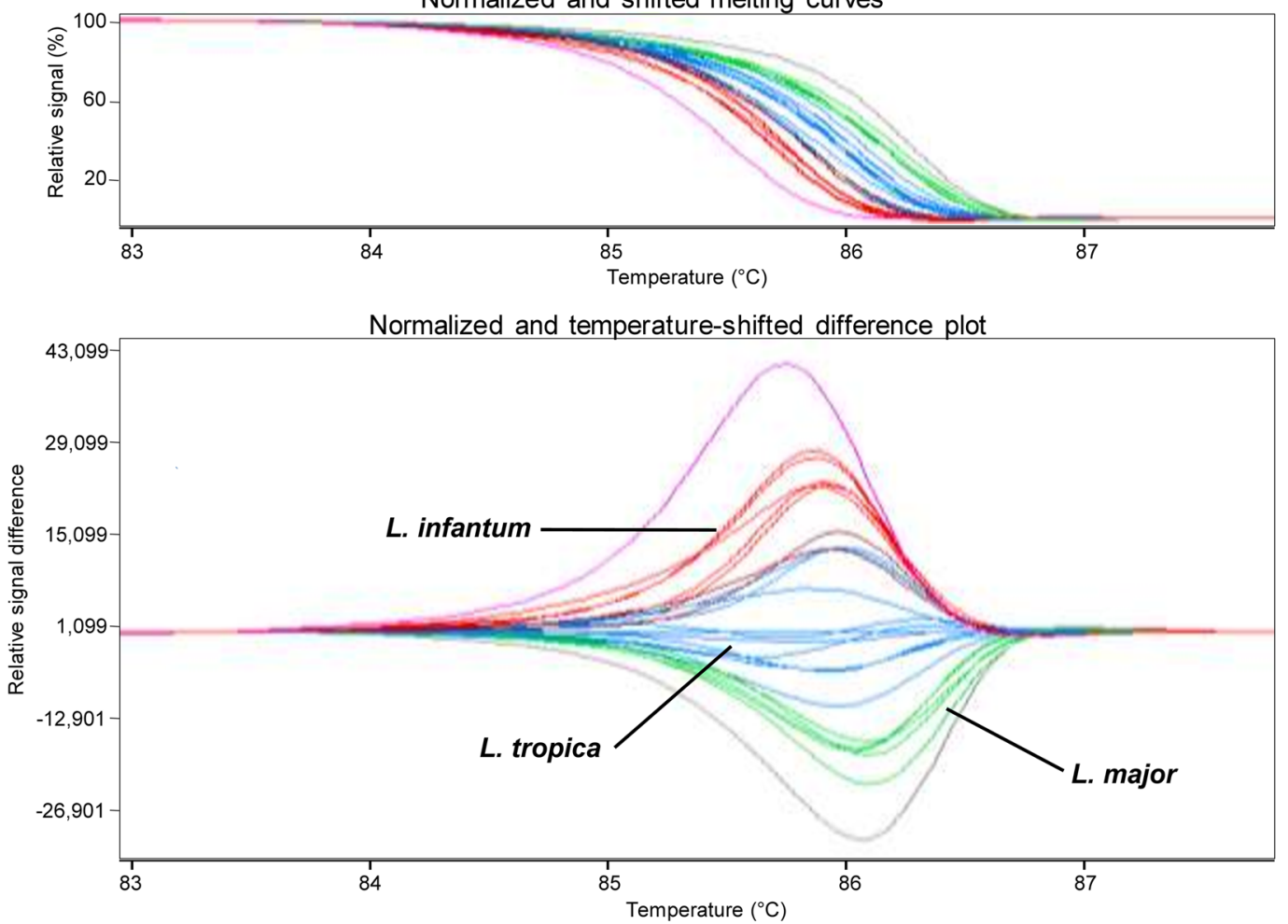

Fig. 1 (See legend on previous page.) 


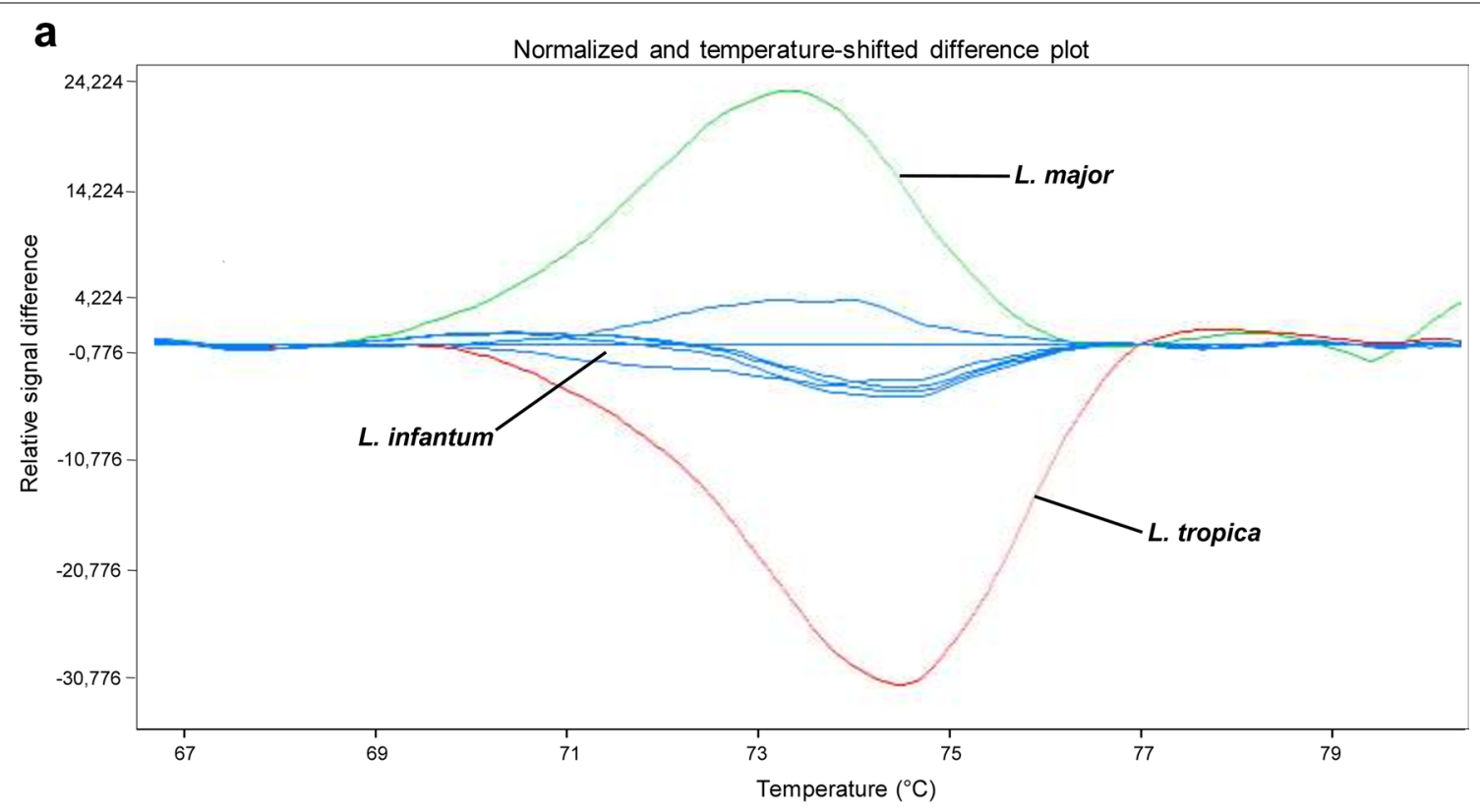

b

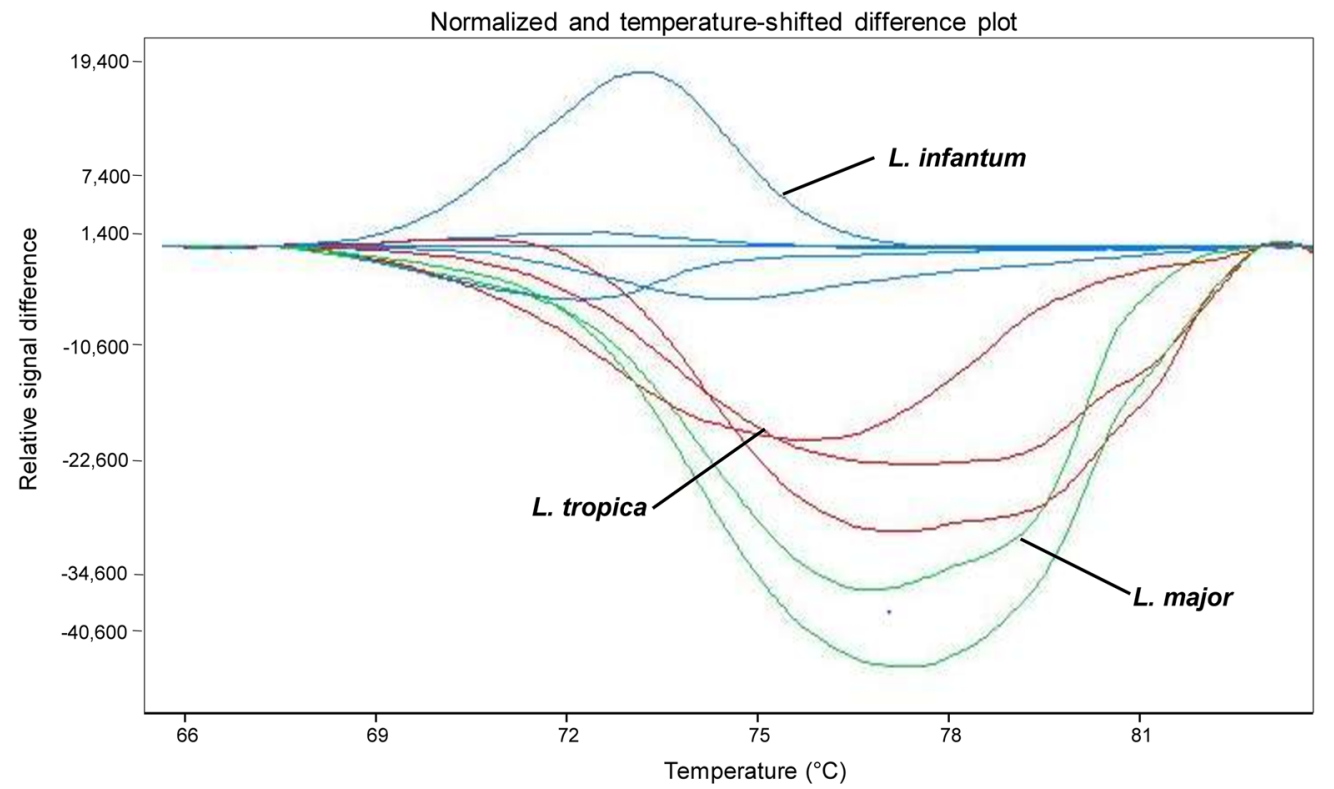

Fig. 2 Gene scanning analysis of PCR-HRM from reservoir samples, using 7SL RNA gene. a Infection of dogs with L. infantum. Tested samples are $\operatorname{dog} 10, \operatorname{dog} 32, \operatorname{dog} 37, \operatorname{dog} 43$, and dog 47. b Identification of Leishmania species infecting hedgehog, Meriones, and dogs. Tested samples are hedgehogs (CEZ4, PES1, and FES1), Meriones (SMZ3, SMZ4, and SMZ1), and dogs (dog 3 and dog 4). Reference isolates correspond to L. infantum, L. major, and L. tropica. See Table 1 for an explanation of samples codes

all tested species, while 7SL PCR-HRM allowed to detect different DNA amounts over the three species. These discrepancies are probably due to the target sequences as well as amplification conditions. Indeed, $0.02 \mathrm{pg}$ DNA were detected using the same primers in 7SL PCR-HRM, in a previous study where in vitro-cultured parasite species from the Old World, were used in different experimental conditions (addition of DMSO and touchdown in the annealing step), as done in our work [17]. In another study targeting the ITS1 rRNA region, 0.05 pg DNA was detected by PCR-HRM from Old World cultured promastigotes [16]. Various DNA amounts, ranging from $50 \mathrm{pg}$ to $500 \mathrm{fg}$, representing the limit of detection, were also found in a recent study were PCR-HRM targeting the amino acid permease 3 (aap3) gene was tested on 

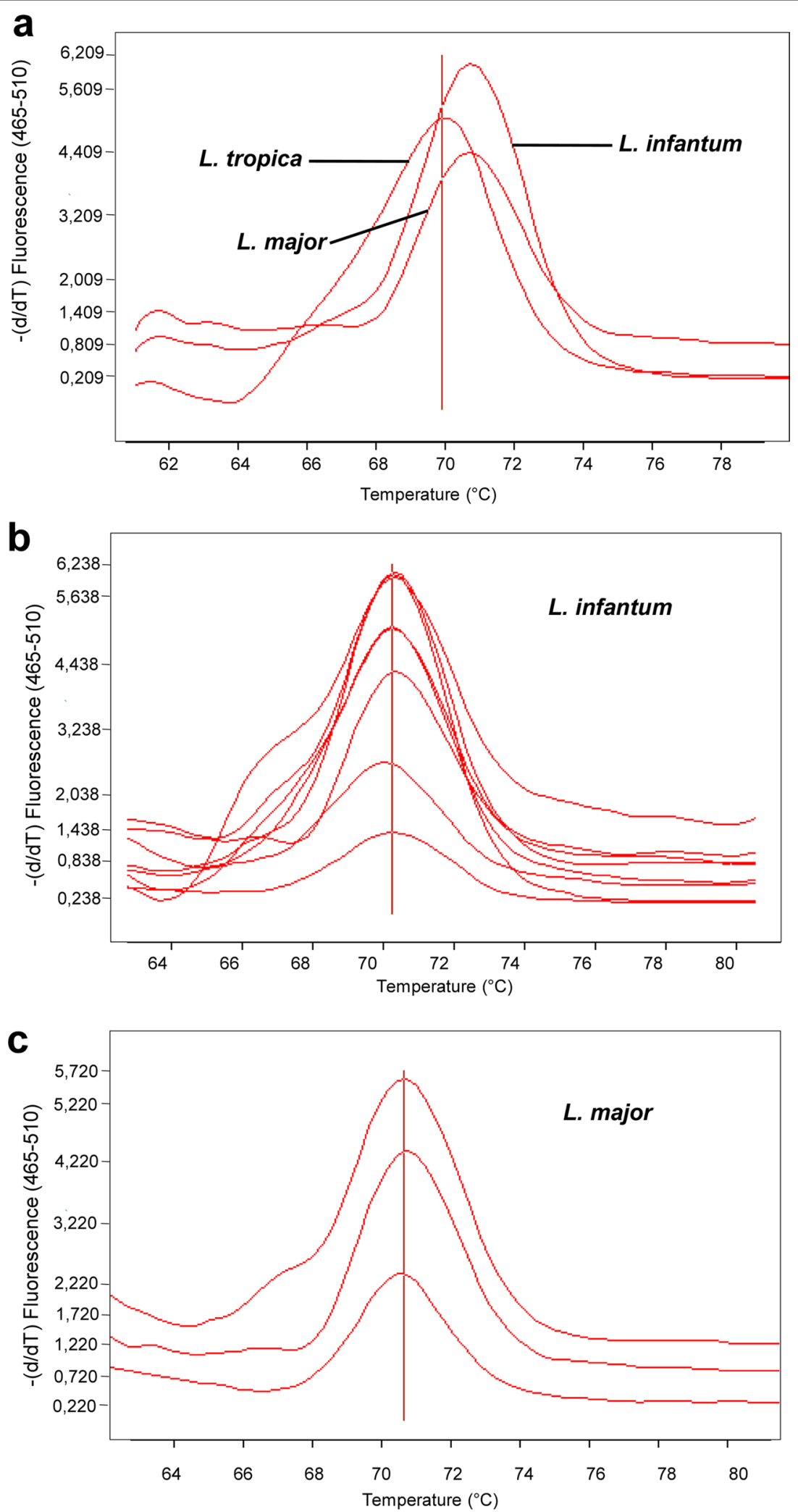

Fig. 3 Melting peaks analysis of PCR-HRM from reservoir samples, using HSP70 gene. a Melting peaks of reference isolates L. infantum, L. major, and L. tropica. $\mathbf{b}$ Infection of reservoir samples with $L$. infantum. $\mathbf{c}$ Infection of reservoir samples with L. major. Tested samples are dog 47, CED1, SMZ3, CMZ4, SMZ2, SMZ1, SMZ7, RMZ4, and FMZ1. See Table 1 for explanation of sample codes 
different Leishmania species from the Old World and the New World [52].

The 7SL RNA and HSP70 PCR-HRM tools used here showed their applicability on samples collected from field animals constituting confirmed or potential reservoirs of Leishmania in Tunisia, which brings new information regarding identity/infectivity of reservoir hosts within a specific endemic region. It is worth mentioning here that there are very few publications addressing leishmaniasis diagnosis using HRM in Old World settings. In addition, previously developed PCR-HRM were mostly applied to in vitro-cultured parasites and validated in clinical human samples [15-17], naturally infected sand flies or experimentally infected mice [15, 52], and rarely on reservoir animals [16]. PCR-HRM results on field animals with both 7SL and HSP70 gene targets were nicely concordant and demonstrated co-infection of all tested hedgehogs with $L$. major and L. infantum, as shown by differential infection of samples of the same specimen with different Leishmania species. However, co-infection in the same sample of a given hedgehog specimen was not found, contrary to what has been previously described $[9,10]$. This could be explained by a targeted amplification that results in competitive priming and preferential amplification of sequences corresponding to a specific species [53]. Demonstrating Leishmania infection followed by species identification in hedgehogs was previously realized in our laboratory using combined conventional PCR and PCR-RFLP, using different targets. Indeed, amplification of kinetoplast minicircles [54], rRNA gene [55], and nested PCR-RFLP targeting a repetitive intergenic sequence $[56,57]$ were combined to show natural Leishmania infection of hedgehogs in Tunisia $[9,10]$. A combination of different PCR assays was necessary, since amplification of parasite DNA from field samples poses challenges with respect to sensitivity and specificity, as parasite load is generally markedly lower in proportion to host DNA [58]. This favors the use of PCR-HRM, which is characterized by very high sensitivity of detection, especially in field sampling. On the other hand, our results further corroborate previous studies that showed natural Leishmania infection of hedgehogs and suggest its potential role as a reservoir host, not only in Tunisia $[9,10]$ but also in Algeria, where it was first described [8], and recently in Iran [7].

Natural Leishmania infection of Meriones rodents is shown here for the first time by PCR-HRM. Indeed, among the seven studied $M$. shawi specimens, three were found to be infected exclusively by $L$. major, while co-infections with $L$. major and $L$. infantum were also recorded in four of them. Finding these rodents infected with $L$. major is not surprising, since they are considered one of the main reservoir animals of ZCL in both
Tunisia and other Mediterranean countries [38, 59, 60]. However, finding L. infantum infecting Meriones has also been documented in a few studies, in Morocco [47], Iran [61], and China [62]. On the other hand, mixed Leishmania species infection of natural reservoirs has rarely been reported. Indeed, within ZCL endemic regions in Iran, mixed infection with $L$. major and $L$. turanica was found in gerbils belonging to the species Rhombomys opimus and Meriones libycus [63], while co-infection by $L$. major and L. turanica or by L. major and L. gerbilli was described in R. opimus rodents [64].

In this study, infection of dogs by L. infantum was also demonstrated by 7SL and HSP70 PCR-HRM. Indeed, with both targets, eight out of 12 tested dogs were found to be infected with L. infantum. These findings corroborate previous knowledge of the role of dogs as the main reservoir of L. infantum causing VL in the MENA [Middle East and North Africa] region [60]. Nonetheless, it is worth noting here that all tested dogs presented with no leishmaniasis symptoms, which further shows the usefulness of these PCR-HRM tools in the diagnosis of canine leishmaniasis (CanL). Indeed, even when they are asymptomatic, dogs are considered carriers and are as infectious as the symptomatic ones $[65,66]$. Thus, using sensitive tools like PCR-HRM for CanL diagnosis will enhance the estimation of the real number of infected dogs and better evaluate the extent of infection, thus enhancing the effectiveness of control programs.

\section{Conclusions}

The PCR-HRM assays developed in this study constitute valuable tools for molecular detection and identification of Leishmania parasites in reservoir hosts and can be easily implemented in epidemiological surveys in endemic regions, thus providing important insights for future control and prevention strategies for public and animal health.

\section{Abbreviations \\ 7SL RNA: 7 Spliced leader RNA gene; CanL: Canine leishmaniasis; CCL: Chronic cutaneous leishmaniasis; CL: Cutaneous leishmaniasis; Ct: Threshold cycle; DMSO: Dimethyl sulfoxide; HSP70: Heat shock protein 70 gene; ITS1: Riboso- mal internal transcribed spacer 1; kDNA: Kinetoplast DNA; MLST: Multilocus sequence typing; PCR-HRM: PCR high-resolution melting analysis; PO: Acidic ribosomal phosphoprotein; RFLP: Restriction fragment length polymorphism; SCL: Sporadic cutaneous leishmaniasis; SNP: Single nucleotide polymorphism; SSU rRNA: Small subunit ribosomal RNA genes; Tm: Melting temperature; $\mathrm{VL}$ : Visceral leishmaniasis; ZCL: Zoonotic cutaneous leishmaniasis.}

\section{Supplementary Information}

The online version contains supplementary material available at https://doi. org/10.1186/s13071-021-05138-x. 
Additional file 1: Table S1. Morphological criteria of the studied Meriones and hedgehogs, date of capture, and geographical origins.

Additional file 2: Table S2. List of collected samples from the studied dogs, Meriones, and hedgehogs.

Additional file 3: Table S3. List of Leishmania strains used in conventional PCR and PCR-HRM reaction setups.

Additional file 4: Table S4.Conventional PCRs primers sequences, reactions, and cycling conditions.

Additional file 5: Figure S1. Conventional PCR targeting 7SL RNA and HSP70 genes. a Conventional 7SL PCR. Samples from hedgehogs are 1, SED1; 2, FES1. Samples from Meriones are 3, FMZ4; 4, SMZ1; 5, SMZ2; 6, GMZ2; 7, SMZ7; 8, FMZ7; 9, RMZ4; 10, FMZ5. Samples from dogs are 11, dog 32. 12, negative (no DNA). b Conventional HSP70 PCR. Samples from Meriones are 1, SMZ2; 2, GMZ2; 3, SMZ1; 4, SMZ7; 5, FMZ7. 9, negative (no DNA). Reference Leishmania DNA are Lt, L. tropica (L75); Lm, L. major (EMPA10); Li, L. infantum (LV50). -, negative (no DNA). M, molecular weight marker $100 \mathrm{bp}$. All marked sizes are in bp.

Additional file 6: Figure S2. PO PCR. Samples correspond to positive controls from mammalian DNA (lanes 1 to 3 ) and DNA from dogs' blood (lanes 4 to 9). 1, PBMC (peripheral blood mononuclear cell); 2, ADNh (human DNA); 3, ADNH (hedgehog); 4, dog 10; 5, dog 32; 6, dog 47; 7, dog 49; 8 , dog 37; 9, dog 43;-, negative control (no DNA). M, molecular weight marker 50 bp. All marked sizes are in bp.

Additional file 7: Table S5. BLAST analysis confirming Leishmania identity in a selection of sequences generated upon direct sequencing of conventional HSP70 PCR products and PCR-HRM products of 7SL and HSP70 targets.

Additional file 8: Figure S3. Sensitivity of PCR-HRM targeting 7SL RNA and HSP70 genes. Detection limit of PCR-HRM using 7SL RNA and HSP70 genes was determined using tenfold dilutions of DNA from each reference Leishmania isolate, representing L. infantum (MHOM/TN/94/LV50), L. major (MHOM/TN/2011/EMPA10), and L. tropica (MHOM/IQ/65/L75). a. 7SL PCR-HRM using L. infantum DNA b. HSP70 PCR-HRM using L. infantum DNA. c. 7SL PCR-HRM using L. major DNA d. HSP70 PCR-HRM using L. major DNA. e. 7SL PCR-HRM using L. tropica DNA f. HSP70 PCR-HRM using $L$. tropica DNA. The right sections of the figures show the tested samples, which are color-coded according to the amplification result, red when positive and green when negative. In all panels, sample codes correspond to the following DNA amounts: A: 20 ng; B: 10 ng; C: 1 ng; D: 0.1 ng; E: 0.01 ng; F: 0.001 ng; G: 0.0001 ng; H: negative control (no DNA).

\section{Acknowledgements}

The authors are grateful to the local team of veterinarians in the region of El Kef who helped in the collection of blood samples from dogs.

\section{Authors' contributions}

Study design: SG. Specimen collection and identification: JC, AR, HSO, AB, and YM. Molecular analyses: MD, AT, GB, and SG. Data interpretation: MD, AT, $G B$, YM, and SG. Contributed reagents/materials/equipment: $A B$, YM, and IG. Manuscript preparation: MD and SG. All authors substantively revised the manuscript. All authors read and approved the final manuscript.

\section{Funding}

This work was financed by a special grant from Pasteur Institute of Tunis, "Programmes Collaboratifs Internes, PCI" received through a collaboration between the "Laboratoire d'Epidémiologie Moléculaire et Pathologie Expérimentale appliquée aux Maladies Infectieuses (LR16IPT04)" and the "Laboratoire d'épidémiologie et Microbiologie Vétérinaire (LR16IPT03)" at Institut Pasteur de Tunis, Université Tunis El Manar, Tunis, Tunisia. This work was also partially financed from the Ministry of Higher Education and Research in Tunisia through the "Laboratoire d'Epidémiologie Moléculaire et Pathologie Expérimentale appliquée aux Maladies Infectieuses" (LR16IPT04).

\section{Availability of data and materials}

Not applicable.

\section{Declarations}

\section{Ethics approval and consent to participate}

Capturing and sampling of animals was approved by the ethical committee of Pasteur Institute of Tunis (reference number 2017/11/I/LR11/PT03). Animal handling, euthanasia, and disposal of dead animals were performed following the guidelines of the guiding principles for biomedical research involving animals. Blood samples from dogs were collected by veterinarians according to the good practices of veterinary medicine.

\section{Consent for publication}

Not applicable.

\section{Competing interests}

The authors declare that they have no competing interests.

\section{Author details}

${ }^{1}$ Laboratoire d'Epidémiologie Moléculaire Et Pathologie Expérimentale Appliquée Aux Maladies Infectieuses (LR16IPT04), Institut Pasteur de Tunis, Université Tunis El Manar, Tunis, Tunisia. ${ }^{2}$ Laboratoire d'épidémiologie Et Microbiologie Vétérinaire (LR16IPT03), Institut Pasteur de Tunis, Université Tunis El Manar, Tunis, Tunisia. ${ }^{3}$ Laboratoire Des Virus, Vecteurs Et Hôtes (LR20IPT02), Institut Pasteur de Tunis, Université Tunis El Manar, Tunis, Tunisia. ${ }^{4}$ Faculté Des Sciences de Tunis, Université Tunis El Manar, Tunis, Tunisia.

Received: 9 August 2021 Accepted: 19 December 2021

Published online: 08 January 2022

\section{References}

1. Akhoundi M, Kuhls K, Cannet A, Votýpka J, Marty P, Delaunay P, et al. A historical overview of the classification, evolution, and dispersion of Leishmania parasites and sandflies. PLoS Negl Trop Dis. 2016;10:e0004349.

2. Maia C, Dantas-Torres F, Campino L. Parasite biology: the reservoir hosts. In: Bruschi F, Gradoni L, editors. The Leishmaniases: old neglected tropical diseases. Berlin: Springer; 2018. p. 79-106.

3. Aoun K, Jeddi F, Amri F, Ghrab J, Bouratbine A. Current epidemiological data on visceral leishmaniasis in Tunisia. Med Mal Infect. 2009;39:775-9.

4. Fathallah-Mili A, Saghrouni F, BenSaid Z, Saadi-BenAoun Y, Guizani I, BenSaid M. Retrospective analysis of leishmaniasis in Central Tunisia: an update on emerging epidemiological trends. In: Rodriguez-Morales A, editor. Current topics in tropical medicine. New York: InTech; 2012. p. 227-52.

5. Chaara D, Bañuls AL, Haouas N, Talignani L, Lami P, Mezhoud H, et al. Comparison of Leishmania killicki (syn. L. tropica) and Leishmania tropica population structure in Maghreb by microsatellite typing. PLoSNegl Trop Dis. 2015;9:e0004204.

6. Jaouadi K, Haouas N, Chaara D, Gorcii M, Chargui N, Augot D, et al. First detection of Leishmania killicki (Kinetoplastida, Trypanosomatidae) in Ctenodactylusgundi (Rodentia, Ctenodactylidae), a possible reservoir of human cutaneous leishmaniasis in Tunisia. Parasit Vectors. 2011:4:159.

7. Pourmohammadi B, Mohammadi-Azni S. Molecular detection of Leishmania major in Hemiechinus auritus, a potential reservoir of zoonotic cutaneous leishmaniasis in Damghan. Iran J Arthropod Borne Dis. 2019;13:334-43.

8. Tomás-Pérez M, Khaldi M, Riera C, Mozo-León D, Ribas A, Hide M, et al. First report of natural infection in hedgehogs with Leishmania major, a possible reservoir of zoonotic cutaneous leishmaniasis in Algeria. Acta Trop. 2014;135:44-9.

9. Chemkhi J, Souguir H, Ali IB, Driss M, Guizani I, Guerbouj S. Natural infection of Algerian hedgehog, Atelerix algirus (Lereboullet 1842) with Leishmania parasites in Tunisia. Acta Trop. 2015;150:42-51.

10. Souguir-Omrani H, Chemkhi J, Fathallah-Mili A, Saadi-BenAoun Y, BelHadjAli I, Guizani I, et al. Paraechinus aethiopicus (Ehrenberg 1832) and Atelerix algirus (Lereboullet 1842) hedgehogs: possible reservoirs of endemic leishmaniases in Tunisia. Infect Genet Evol. 2018;63:219-30.

11. Schönian G, Nasereddin A, Dinse N, Schweynoch C, Schallig HDFH, Presber W, et al. PCR diagnosis and characterization of Leishmania in local and imported clinical samples. Diagn Microbiol Infect Dis. 2003;47:349-58. 
12. Słomka M, Sobalska-Kwapis M, Wachulec M, Bartosz G, Strapagiel D. High Resolution Melting (HRM) for high-throughput genotyping - limitations and caveats in practical case studies. Int J Mol Sci. 2017;18:2316.

13. Tamburro M, Ripabelli G. High Resolution Melting as a rapid, reliable, accurate and cost-effective emerging tool for genotyping pathogenic bacteria and enhancing molecular epidemiological surveillance: a comprehensive review of the literature. Ann Ig. 2017:29:293-316.

14. Hernández C, Alvarez C, González C, Ayala MS, León CM, Ramírez JD. Identification of six New World Leishmania species through the implementation of a High-Resolution Melting (HRM) genotyping assay. Parasit Vectors. 2014;7:501.

15. Zampieri RA, Laranjeira-Silva MF, Muxel SM, de Lima ACS, Shaw JJ, FloeterWinter LM. High Resolution Melting analysis targeting hsp70 as a fast and efficient method for the discrimination of Leishmania species. PLoS Negl Trop Dis. 2016;10:e0004485.

16. Talmi-Frank D, Nasereddin A, Schnur LF, Schönian G, Töz SO, Jaffe CL, et al. Detection and identification of old world Leishmania by high resolution melt analysis. PLoSNegl Trop Dis. 2010;4:e581.

17. Nasereddin A, Jaffe CL. Rapid diagnosis of Old World Leishmaniasis by high-resolution melting analysis of the 7SL RNA gene. J Clin Microbiol. 2010;48:2240-2.

18. Kuang Z, Zhang C, Pang H, Ma Y. A rapid high-resolution melting method for differentiation of Leishmania species targeting lack gene. Acta Trop. 2018:178:103-6.

19. Corbet GB. The family Erinaceidae: a synthesis of its taxonomy, phylogeny, ecology and zoogeography. Mammal Rev. 1988;18:117-72.

20. El-Farhati H, Jaziri B, Hizem MW, Nouira S. Distribution, bioclimatic niche and sympatry of two erinaceidae in Tunisia. Afr J Ecol. 2019;00:1-18.

21. Guerbouj S, Djilani F, Bettaieb J, Lambson B, Diouani MF, Ben Salah A, et al. Evaluation of a gp63-PCR based assay as a molecular diagnosis tool in canine leishmaniasis in Tunisia. PLoS ONE. 2014:9:e105419.

22. Ashford DA, Bozza M, Freire M, Miranda JC, Sherlock I, Eulalio C, et al. Comparison of the polymerase chain reaction and serology for the detection of canine visceral leishmaniasis. Am J Trop Med Hyg. 1995;53:251-5.

23. Costa JM, Garcia-Hermoso D, Olivi M, Cabaret O, Farrugia C, Lecellier $\mathrm{G}$, et al. Genotyping of Candida albicans using length fragment and high-resolution melting analyses together with minisequencing of a polymorphic microsatellite locus. J MicrobiolMethods. 2010;80:306-9.

24. Chibssa TR, Settypalli TBK, Berguido FJ, Grabherr R, Loitsch A, Tuppurainen E, et al. An HRM Assay to differentiate sheeppox virus vaccine strains from sheeppox virus field isolates and other capripoxvirus species. SciRep. 2019;9:6646.

25. Erster O, Stram R, Menasherow S, Rubistein-Giuni M, Sharir B, Kchinich E, et al. High-resolution melting (HRM) for genotyping bovine ephemeral fever virus (BEFV). Virus Res. 2017;229:1-8.

26. Njage PMK, Buys E. A high resolution DNA melting curve analysis for the rapid and efficient molecular diagnostics of extended spectrum $\beta$-Lactamase Determinants from foodborne Escherichia coli. Microorganisms. 2020:8:E90.

27. Arefzadeh S, Azimi T, Nasiri MJ, Nikpor Z, Dabiri H, Doustdar F, et al. High-resolution melt curve analysis for rapid detection of rifampicin resistance in Mycobacterium tuberculosis: a single-centre study in Iran. New Microbes New Infect. 2020;35:100665.

28. Gopaul KK, Sells J, Lee R, Beckstrom-Sternberg SM, Foster JT, Whatmore AM. Development and assessment of multiplex high resolution melting assay as a tool for rapid single-tube identification of five Brucella species. BMC Res Notes. 2014;7:903.

29. Wang J, Liu A, Zhang S, Gao S, Rashid M, Li Y, et al. High resolution melting analysis of the $18 \mathrm{~S}$ rRNA gene for the rapid diagnosis of bovine babesiosis. Parasit Vectors. 2019:12:523.

30. Kamaliddin C, Joste V, Hubert V, Kendjo E, Argy N, Houze S. Evaluation of PCR to monitor Plasmodium falciparum treatment efficacy in a nonendemicity setting. J ClinMicrobiol. 2019;58:e01080-e1119.

31. Wang J, Yang J, Gao S, Liu A, Rashid M, Li Y, et al. Rapid detection and differentiation of Theileria annulata, T. orientalis and T. sinensis using highresolution melting analysis. Ticks Tick Borne Dis. 2020;11:101312.

32. Mohammad Rahimi H, Pourhosseingholi MA, Yadegar A, Mirjalali H, Zali MR. High-resolution melt curve analysis: A real-time based multipurpose approach for diagnosis and epidemiological investigations of parasitic infections. Comp Immunol Microbiol Infect Dis. 2019;67:101364.
33. Hosseini-Safa A, Mohebali M, Hajjaran H, Akhoundi B, Zarei Z, Arzamani K, et al. High resolution melting analysis as an accurate method for identifying Leishmania infantum in canine serum samples. J Vector Borne Dis. 2018:55:315-20.

34. Ahuja K, Vats A, Beg MA, Kariyawasam KKGDUL, Chaudhury A, Chatterjee $M$, et al. High resolution melting based method for rapid discriminatory diagnosis of co-infecting Leptomonas seymouri in Leishmania donovaniinduced leishmaniasis. Parasitol Int. 2019;75:102047.

35. Rojas-Jaimes J, Rojas-Palomino N, Pence J, Lescano AG. Leishmania species in biopsies of patients with different clinical manifestations identified by high resolution melting and nested PCR in an Endemic district in Peru. Parasite Epidemiol Control. 2019;4:e00095.

36. Fichet-Calvet E, Jomâa I, Ben Ismail R, Ashford RW. Leishmania major infection in the fat sand rat Psammomys obesus in Tunisia: interaction of host and parasite populations. Ann Trop Med Parasitol. 2003;97:593-603.

37. Ghawar W, Snoussi MA, Hamida NBH, Boukthir A, Yazidi R, Chaâbane S, et al. First report of natural infection of least weasel (Mustelanivalis Linnaeus, 1776) with Leishmania major in Tunisia. Vector Borne Zoonotic Dis. 2011;11:1507-9.

38. Ghawar W, Toumi A, Snoussi M-A, Chlif S, Zâatour A, Boukthir A, et al. Leishmania major infection among Psammomys obesus and Meriones shawi: reservoirs of zoonotic cutaneous leishmaniasis in SidiBouzid (Central Tunisia). Vector Borne Zoonotic Dis. 2011;1 1:1561-8.

39. Bousslimi N, Ben-Ayed S, Ben-Abda I, Aoun K, Bouratbine A. Natural infection of North African gundi (Ctenodactylusgundi) by Leishmania tropica in the focus of cutaneous leishmaniasis, Southeast Tunisia. Am J Trop Med Hyg. 2012;86:962-5.

40. Miró G, Cardoso L, Pennisi MG, Oliva G, Baneth G. Canine leishmaniosisnew concepts and insights on an expanding zoonosis: part two. Trends Parasitol. 2008;24:371-7.

41. Santos FJA, Nascimento LCS, Silva WB, Oliveira LP, Santos WS, Aguiar DCF, et al. First report of canine infection by Leishmania (Viannia) guyanensis in the Brazilian Amazon. Int J Environ Res Public Health. 2020;17:8488.

42. de Castro Ferreira E, Pereira AAS, Silveira M, Margonari C, Marcon GEB, de Oliveira França A, et al. Leishmania (V.) braziliensis infecting bats from Pantanal wetland, Brazil: first records for Platyrrhinuslineatus and Artibeusplanirostris. Acta Trop. 2017;172:217-22.

43. Castro LS, Dorval MEC, Matheus LMD, Bednaski AV, Facco GG, Silveira M, et al. Leishmania presence in bats in areas endemic for leishmaniasis in central-west Brazil. Int J Parasitol Parasites Wild I. 2020;11:261-7.

44. Lemma W, Bizuneh A, Tekie H, Belay H, Wondimu H, Kassahun A, et al. Preliminary study on investigation of zoonotic visceral leishmaniasis in endemic foci of Ethiopia by detecting Leishmania infections in rodents. Asian Pac J Trop Med. 2017;10:418-22.

45. Escobar TA, Dowich G, Dos Santos TP, Zuravski L, Duarte CA, Lübeck I, et al. Assessment of Leishmania infantum infection in equine populations in a canine visceral leishmaniosis transmission area. BMC VetRes. 2019;15:381.

46. Rocha AVVO, Moreno BFS, Cabral AD, Louzeiro NM, Miranda LM, dos Santos VMB, et al. Diagnosis and epidemiology of Leishmania infantum in domestic cats in an endemic area of the Amazon region, Brazil. Vet Parasitol. 2019;273:80-5.

47. Echchakery M, Chicharro C, Boussaa S, Nieto J, Carrillo E, Sheila O, et al. Molecular detection of Leishmania infantum and Leishmania tropica in rodent species from endemic cutaneous leishmaniasis areas in Morocco. Parasit Vectors. 2017;10:454

48. Tsukayama P, Núñez JH, De Los Santos M, Soberón V, Lucas CM, Matlashewski G, et al. A FRET-based real-time PCR assay to identify the main causal agents of New World tegumentary leishmaniasis. PLoS Negl Trop Dis. 2013;7:e1956.

49. Tse MY, Ashbury JE, Zwingerman N, King WD, Taylor SA, Pang SC. A refined, rapid and reproducible high resolution melt (HRM)-based method suitable for quantification of global LINE-1 repetitive element methylation. BMC Res Notes. 2011:4:565.

50. Wu WM, Tsai HJ, Pang JHS, Wang HS, Hong HS, Lee YS. Touchdown thermocycling program enables a robust single nucleotide polymorphism typing method based on allele-specific real-time polymerase chain reaction. Anal Biochem. 2005;339:290-6.

51. Korbie DJ, Mattick JS. Touchdown PCR for increased specificity and sensitivity in PCR amplification. Nat Protoc. 2008;3:1452-6. 
52. Müller KE, Zampieri RA, Aoki Jl, Muxel SM, Nerland AH, Floeter-Winter LM. Amino acid permease 3 (aap3) coding sequence as a target for Leishmania identification and diagnosis of leishmaniases using high resolution melting analysis. Parasit Vectors. 2018;11:421

53. Flaherty BR, Talundzic E, Barratt J, Kines KJ, Olsen C, Lane M, et al. Restriction enzyme digestion of host DNA enhances universal detection of parasitic pathogens in blood via targeted amplicon deep sequencing. Microbiome. 2018;6:164.

54. Reale S, Maxia L, Vitale F, Glorioso NS, Caracappa S, Vesco G. Detection of Leishmania infantum in dogs by PCR with lymph node aspirates and blood. J ClinMicrobiol. 1999;37:2931-5.

55. Spanakos G, Patsoula E, Kremastinou T, Saroglou G, Vakalis N. Development of a PCR-based method for diagnosis of Leishmania in blood samples. Mol Cell Probes. 2002;16:415-20.

56. Piarroux R, Fontes M, Perasso R, Gambarelli F, Joblet C, Dumon H, et al. Phylogenetic relationships between Old World Leishmania strains revealed by analysis of a repetitive DNA sequence. Mol Biochem Parasitol. 1995;73:249-52

57. Tordini G, Giaccherini R, Pacenti L, Miracco C, Zazzi M, Zanelli G. Cutaneous leishmaniasis: usefulness of PCR on paraffin-embedded skin biopsies as part of routine investigation. Ann Trop Med Parasitol. 2007;101:745-9.

58. Tsakmakidis I, Angelopoulou K, Dovas Cl, Dokianakis E, Tamvakis A Symeonidou I, et al. Leishmania infection in rodents in Greece. Trop Med Int Health. 2017;22:1523-32

59. El Hamouchi A, Daoui O, AitKbaich M, Mhaidi I, El Kacem S, Guizani I, et al. Epidemiological features of a recent zoonotic cutaneous leishmaniasis outbreak in Zagora province, southern Morocco. PLoS Negl Trop Dis. 2019;13:e0007321.

60. Tabbabi A. Review of leishmaniasis in the Middle East and North Africa. Afr Health Sci. 2019;19:1329-37.

61. Mohebali M, Moradi-Asl E, Rassi Y. Geographic distribution and spatial analysis of Leishmania infantum infection in domestic and wild animal reservoir hosts of zoonotic visceral leishmaniasis in Iran: a systematic review. J Vector Borne Dis. 2018;55:173-83.

62. Gao CH, Wang JY, Zhang S, Yang YT, Wang Y. Survey of wild and domestic mammals for infection with Leishmania infantum following an outbreak of desert zoonotic visceral leishmaniasis in Jiashi, People's Republic of China. PLoS ONE. 2015;10:e0132493.

63. Akhoundi M, Mohebali M, Asadi M, Mahmodi MR, Amraei K, Mirzaei A. Molecular characterization of Leishmania spp. in reservoir hosts in endemic foci of zoonotic cutaneous leishmaniasis in Iran. Folia Parasitol (Praha). 2013;60:218-24

64. Akhavan AA, Yaghoobi-Ershadi MR, Khamesipour A, Mirhendi H, Alimohammadian MH, Rassi Y, et al. Dynamics of Leishmania infection rates in Rhombomysopimus (Rodentia: Gerbillinae) population of an endemic focus of zoonotic cutaneous leishmaniasis in Iran. Bull SocPatholExot. 2010;103:84-9.

65. Molina R, Amela C, Nieto J, San-Andrés M, González F, Castillo JA, et al. Infectivity of dogs naturally infected with Leishmania infantum to colonized Phlebotomus perniciosus. Trans R Soc Trop Med Hyg. 1994;88:491-3.

66. Michalsky EM, Rocha MF, da Rocha LACVM, França-Silva JC, Pires MQ, Oliveira FS, et al. Infectivity of seropositive dogs, showing different clinical forms of leishmaniasis, to Lutzomyialongipalpis phlebotomine sand flies. Vet Parasitol. 2007;147:67-76.

\section{Publisher's Note}

Springer Nature remains neutral with regard to jurisdictional claims in published maps and institutional affiliations.

Ready to submit your research? Choose BMC and benefit from:

- fast, convenient online submission

- thorough peer review by experienced researchers in your field

- rapid publication on acceptance

- support for research data, including large and complex data types

- gold Open Access which fosters wider collaboration and increased citations

- maximum visibility for your research: over $100 \mathrm{M}$ website views per year

At BMC, research is always in progress.

Learn more biomedcentral.com/submissions 